\title{
EDITORIALS \\ Mortality among people with mental disorders
}

EDITORIALI

La mortalità delle persone con disturbi mentali

\author{
FRANCESCO AMADDEO, Guest Editor \\ and MICHELE TANSELLA, Editor
}

Mortality among psychiatric patients has been found to be higher than the general population, not only in those long-term residents in old-fashioned psychiatric hospitals or attending hospital-based psychiatric services (Harris \& Barraclough, 1998) but also in those treated in modern community-based systems of care (Amaddeo et al., 1995; Grigoletti et al., 2009).

The hypotheses about why people with psychiatric disorders are more likely to die than the rest of the population are many, different and often supported by contradictory data.

Psychiatric patients are at higher risk of suicide, accidental or violent death in general, and this association is quite obvious and well known. Less clear is the association that links psychiatric morbidity to a higher mortality for natural causes. A correlation between organic diseases and mental disorders is evident (Buist-Bouwman et al., 2005), but a comprehensive explanation of the excess morbidity and mortality of these populations is still lacking. A possible explanation could be the unhealthy lifestyle of people with psychiatric disorders (smoking, alcohol abuse, dietary habits, etc.), especially those with severe mental illnesses (Brown et al., 2000). Other data suggest that medical assistance could be less adequate for psychiatric patients than for people without psychiatric disorders (Druss et al., 2001). Furthermore, the limited ability of people with mental disorders to recognize and communicate their symptoms of organic diseases could be another possible explanation. Finally, the use of psychotropic drugs has been associated with an excess of cardiac deaths (Appleby et al., 2000; Taylor, 2005).

Other studies showed that mortality of psychiatric patients is also higher, if compared to the general population, when only "avoidable" causes of death are considered (Amaddeo et al., 2007).

Hiroeh et al. (2008) has demonstrated that psychiatric patients not only die more than the general population but
È stato dimostrato che la mortalità dei pazienti psichiatrici è più elevata di quella della popolazione generale, ciò è vero non solo per quei pazienti lungodegenti nei vecchi ospedali psichiatrici (Harris \& Barraclough, 1998) o trattati in servizi psichiatrici hospital-based ma anche per quelli trattati nei moderni servizi community-based (Amaddeo et al., 1995; Grigoletti et al., 2009).

Le ipotesi del perché le persone con un disturbo psichiatrico hanno una maggiore probabilità di morire rispetto al resto della popolazione sono molte, differenti e spesso supportate da dati contraddittori.

I pazienti psichiatrici hanno un rischio più elevato di suicidio, di morte accidentale o violenta in generale; questa associazione è abbastanza ovvia e ben conosciuta. Meno chiara è l'associazione che lega la patologia psichiatrica con una mortalità più elevata per cause naturali. Una correlazione tra malattie organiche e disturbi mentali è evidente (Buist-Bouwman et al., 2005), ma manca ancora una completa spiegazione di un aumento della morbidità e della mortalità di queste popolazioni. Una possibile spiegazione potrebbe essere lo stile di vita poco sano delle persone con disturbi psichiatrici (fumo, abuso di alcool, abitudini alimentari, etc.), specialmente per quelli con disturbi mentali gravi (Brown et al., 2000). Altri dati suggeriscono che l'assistenza medica potrebbe essere meno adeguata per i pazienti psichiatrici che per le persone senza disturbi psichici (Druss et al., 2001). Inoltre, la ridotta capacità delle persone con disturbi mentali a riconoscere e comunicare i sintomi di malattie organiche potrebbe essere un'altra spiegazione. Infine, l'uso di psicofarmaci è stato associato con un eccesso di decessi per cause cardiache (Appleby et al., 2000; Taylor, 2005).

Altri studi hanno dimostrato che la mortalità dei pazienti psichiatrici è ancora più elevata, se confrontata con quella della popolazione generale, quando vengono considerate solo le "cause evitabili" (Amaddeo et al., 2007).

Epidemiologia e Psichiatria Sociale, 19, 1, 2010 
also at a younger age. The problem of increased morbidity and premature death in people with serious mental illness must be addressed with a transformation of the current mental health system and the integration of physical and mental health care, toward a system that utilizes a coordinated, multi-disciplinary holistic approach (Vreeland, 2007). This should be done to overcome some of the multiple barriers that make difficult for individuals with serious mental illness to access a good quality health care.

Research and intervention studies for improving medical care for people with serious mental illness have spanned a continuum of interprofessional involvement, ranging from staff and patient training to on-site consultation by medical staff, multidisciplinary collaborative care approaches, and facilitated linkages between community and mental health and medical providers (Druss \& Newcomer, 2007).

For these reasons, we think that research on mortality and causes of death of psychiatric patients is a worthwhile endeavour for the epidemiological research, as they are a good and strong indicator of the quality of care provided to people with mental disorders.

In this issue of Epidemiologia e Psichiatria Sociale, we publish three Editorials that face different aspects of mortality studies.

The first one, written by Crompton et al. (2010), analyses what we know about mortality risks of people with serious mental illness and which strategies are suggested to deal with this problem. In their Editorial, the Authors emphasize that, apart from an increased risk of suicide, people with schizophrenia or severe mental disorders have an increased risk to die for a wide range of comorbid physical condition, and they describe the evidence that suggest that much of this mortality is avoidable.

The second Editorial is written by De Leo \& Sveticic (2010) and affords the issue of fatal and non-fatal suicidal behaviours. The Authors explain as, despite the poor accuracy in predicting suicidal outcomes, there are ample opportunities for improving the management of suicidal patients, also in hospital wards. Although psychiatric hospitalization is seen as protection from suicidal behaviours, there is evidence that both admissions to a psychiatric ward and recent discharge from it increase the risk. The Authors discusses current knowledge on what elements in the chain of well-intentioned approaches to treating psychiatric illness and suicidality fail to protect this vulnerable population.

The third Editorial, by Biggeri \& Catelan (2010), explains the conceptual and methodological problems related with mortality studies. Selection bias and reverse causation, time-dependent confounders that are also intermediate variables, complex relationship within a life course have to be considered when researchers try to
Hiroeh et al. (2008) hanno dimostrato che i pazienti psichiatrici non solo muoiono di più della popolazione generale, ma anche ad una età più giovane. Il problema di un incremento della morbilità e della morte prematura nelle persone con gravi patologie psichiatriche deve essere affrontato con una trasformazione degli attuali sistemi di assistenza alla salute mentale e con l'integrazione di assistenza medica generale e assistenza psichiatrica, andando cioè verso un sistema che utilizzi una approccio coordinato, multidisciplinare ed olistico (Vreeland, 2007). Questo dovrebbe essere fatto per superare alcune delle molte barriere che rendono difficile, per i soggetti con gravi patologie mentali, l'accesso a cure mediche di buona qualità.

Gli studi, sia di ricerca sia di intervento per il miglioramento dell'assistenza medica alle persone con grave disturbo mentale, hanno indicato un continuum di coinvolgimento inter-professionale che va dalla formazione di operatori e pazienti alla consulenza di uno staff medico, approcci assistenziali collaborativi multidisciplinari e rapporti facilitati tra territorio, servizi di salute mentale e assistenza medica (Druss \& Newcomer, 2007).

Per queste ragioni, noi crediamo che la ricerca sulla mortalità e sulle cause di morte dei pazienti psichiatrici sia un impegno fruttuoso per la ricerca epidemiologica, anche perché esse costituiscono indicatori utili e forti della qualità dell'assistenza fornita alle persone con disturbi mentali.

In questo numero di Epidemiologia e Psichiatria Sociale pubblichiamo tre Editoriali che affrontano diversi aspetti degli studi di mortalità.

Il primo, scritto da Crompton et al. (2010), analizza che cosa sappiamo sul rischio di morte delle persone con grave patologia mentale e quali strategie sono state suggerite per far fronte a questo problema. Gli autori evidenziano il fatto che, escludendo il rischio di suicidio, le persone con schizofrenia o gravi patologie psichiche hanno un maggiore rischio di morire per un ampio range di condizioni fisiche presenti in comorbidità e descrivono le evidenze che suggeriscono come molta di questa mortalità sia evitabile.

Il secondo Editoriale, scritto da De Leo \& Sveticic (2010), affronta il tema dei comportamenti suicidari fatali e non fatali. Gli Autori spiegano come, nonostante la scarsa accuratezza nel prevedere gli esiti del suicidio, ci siano ampie opportunità per migliorare la gestione dei pazienti a rischio suicidario, anche nei reparti ospedalieri. Nonostante l'ospedalizzazione psichiatrica sia vista come una protezione dai comportamenti suicidari, ci sono evidenze che sia il ricovero in reparti psichiatrici che una recente dimissione da essi incrementano il rischio. Gli Autori spiegano quali sono le attuali conoscenze su quali elementi, della catena di un approccio ben intenzionato a

Epidemiologia e Psichiatria Sociale, 19, 1, 2010 
explain the mortality gap between psychiatric patients and the general population. The Authors discuss the effect of using the general population as reference; this would induce an un-healthy population bias which is symmetrical to the well documented "healthy worker effect". Therefore, the use of the general population as reference could produce an overestimation of the risk attributable to the psychiatric illness. Another important issue is the reverse effect: the underlying pathological condition caused the occurrence of psychiatric symptoms (e.g. organic psychosis). Moreover, Biggeri \& Catelan (2010) show the complexity to take into account all the confounders in such a study. To proper account for such confounding we need to split the data in a sequence of short time period and use inverse probability weighting.

\section{REFERENCES}

Amaddeo F., Bisoffi G., Bonizzato P., Micciolo R. \& Tansella M. (1995) Mortality among patients with psychiatric illness. A ten-year case register study in an area with a community-based system of care. British Journal of Psychiatry 166, 783-788.

Amaddeo F., Barbui C., Perini G., Biggeri A. \& Tansella M. (2007). Avoidable mortality of psychiatric patients in an area with a community-based system of mental health care. Acta Psychiatrica Scandinavica 115, 320-325.

Appleby L., Thomas S., Ferrier N., Lewis G., Shaw J. \& Amos T. (2000). Sudden unexplained death in psychiatric in-patients. British Journal of Psychiatry 176, 405-406.

Biggeri A. \& Catelan D. (2010). The methodological and conceptual aspects of mortality studies in psychiatry. Epidemiologia e Psichiatria Sociale 19, 16-20.

Brown S., Hazel I. \& Barraclough B. (2000). Causes of the excess mortality in chizophrenia. British Journal of Psychiatry 177, 212-217.

Buist-Bouwman M.A., De Graaf R., Vollebergh W. \& Ormel J. (2005). Comorbidity of physical and mental disorders and the effect on workloss days. Acta Psychiatrica Scandinavica 111, 436-443.

Crompton D., Groves A. \& McGrath J. (2010). What can we do to reduce the burden of avoidable deaths in those with serious mental illness? Epidemiologia e Psichiatria Sociale 19, 4-7.

Druss B.G. \& Newcomer J.W. (2007). Challenges and solutions to integrating mental and physical health care. Journal of Clinical Psychiatry 68, e 09.

Druss B., Bradford W., Rosenheck R., Radford M. \& Krumholz H. (2001). Quality of medical care and excess mortality in older patients with mental disorders. Archives of General Psychiatry 58, 565. trattare le patologie psichiatriche e il rischio suicidario, falliscono nel proteggere questa popolazione vulnerabile.

Il terzo Editoriale di Biggeri \& Catelan (2010) spiega i problemi concettuali e metodologici relativi agli studi di mortalità. Bias di selezione e causalità in direzione opposta, confondenti tempo-dipendenti che rappresentano anche variabili intermedie, relazioni complesse all' interno del corso della vita devono essere considerati dai ricercatori che cercano di spiegare la differenza di mortalità tra pazienti psichiatrici e popolazione generale. Gli Autori spiegano quale sia l'effetto di utilizzare la popolazione generale come riferimento; ciò produrrebbe un bias legato alla popolazione "non sana" che è simmetrico al ben noto "effetto dei lavoratori sani". L'uso della popolazione generale come riferimento, quindi, potrebbe produrre una sovrastima del rischio attribuibile alla patologia psichiatrica. Un altro importante problema è quello della causalità in direzione opposta: cioè quei casi in cui una sottostante condizione patologica ha causato la comparsa di sintomi psichici (ad esempio, le psicosi organiche). Inoltre, Biggeri \& Catelan (2010) mostrano quanto sia complesso prendere in considerazione tutti i possibili confondenti in uno studio di questo tipo. Per considerare appropriatamente tali confondenti, abbiamo bisogno di dividere $\mathrm{i}$ dati in una sequenza di brevi periodi di tempo ed usare una pesatura della probabilità inversa.

De Leo D. \& Sveticic J. (2010). Suicides in psychiatric in-patients: what are we doing wrong? Epidemiologia e Psichiatria Sociale 19, 8-15.

Harris E.C. \& Barraclough B. (1998). Excess mortality of mental disorder. British Journal of Psychiatry 173, 11-53.

Hiroeh U., Kapur N., Webb R., Dunn G., Mortensen P.B. \& Appleby L. (2008). Deaths from natural causes in people with mental illness: a cohort study. Journal of Psychosomatic Research 64, 275-283.

Grigoletti L., Perini G., Rossi A., Biggeri A., Barbui C., Tansella M. \& Amaddeo F. (2009). Mortality and cause of death among psychiatric patients. A twenty year case-register study in an area with a community-based system of care. Psychological Medicine 39, 1875-1884.

Taylor D. (2005). Psychotropics drugs, torsade de pointes and sudden death. Acta Psychiatrica Scandinavica 111, 169-170.

Vreeland B. (2007). Bridging the gap between mental and physical health: a multidisciplinary approach. Journal of Clinical Psychiatry 68, Suppl. 4, 26-33. 